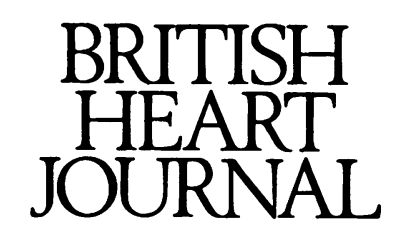

Editorial

\title{
Therapeutic approaches to the control of fibrocellular intimal hyperplasia after angioplasty
}

Enthusiasm for the technique of percutaneous transluminal coronary angioplasty has been tempered by the realisation that $25-50 \%$ of patients have a recurrence of their symptoms in 3-6 months because of restenosis at the site of the original atheromatous lesion. ${ }^{1}$ This is due not to local thrombosis or to the reaccumulation of atheroma but to a rapid growth of vascular smooth muscle cells, both within the intima and migrating from the media, which produces a new lesion known as fibrocellular intimal hyperplasia (FCIH). ${ }^{2}$ There is probably some degree of FCIH in all patients after angioplasty; and its rate of development and final quantity determine the recurrence of angina. FCIH is not unique to the vessel injured by a balloon catheter: intimal hyperplasia is a feature of the "onion skin" lesion of malignant hypertension and systemic sclerosis, the plexiform lesion in the pulmonary arterioles in pulmonary hypertension, and late vein graft occlusion. ${ }^{3}$ More recently intimal hyperplasia has been identified as the cause of the diffuse vascular disease which occurs after cardiac transplantation ${ }^{4}$ and it is the main cause of graft failure after 5 years. The vessel wall seems to have a single response to various insults on the endothelium, media, and adventitia. These insults include chronic immunological injury, sustained pressure increases, rheological changes, or direct physical distension.

\section{Animal models}

There has been considerable debate about the relevance of established animal models of FCIH to the clinical problems, particularly to restenosis after angioplasty. ${ }^{5}$ In some species-for example, the rat-the normal intima consists of only a layer of endothelium and so the vascular smooth muscle cells in FCIH must be derived from the media, while in others, such as humans and the pig, the intima is much more substantial and does contain vascular smooth muscle cells. The contribution of the intimal vascular smooth muscle cells and of cells such as macrophages within the atheromatous plaque to the subsequent development of FCIH is not known. Atheroma has a complex pathology and is many years in the making. The best models of its genesis are expensive and have given us only limited insight. ${ }^{6}$ FCIH on the other hand seems to develop relatively rapidly, particularly after angioplasty when it is established within weeks or a few months. Animal models of FCIH can be easily induced by vascular distension with a Fogarty balloon catheter or angioplasty catheter. The histological appearance of FCIH varies somewhat between species but the accumulation of vascular smooth muscle cells, and extracellular matrix is characteristic of the lesion. ${ }^{5}$ Smooth muscle cells within the lesion have a different phenotype from that of quiescent medial vascular smooth muscle cells, there being a change in the contractile protein isoforms, increased cellular synthetic apparatus, and increased motility of cultured cells derived from the lesion. ${ }^{6-8}$ Synthesis of matrix proteins, such as tenascin, is increased $^{9}$ and tissue type plasminogen activator and urokinase are expressed by the smooth muscle cells of the injured vessel. ${ }^{10}$ Endothelial regrowth may be incomplete though the luminal smooth muscle cells become flattened and superficially are similar in appearance to the endothelium..$^{711}$ There is evidence also of persistent impairment of endothelial cell function. ${ }^{12}$

\section{Clinical trials}

The development of restenosis at the lesion site in patients undergoing angioplasty has been markedly resistant to empirical drug treatment: corticosteroids, aspirin, fish oils, calcium channel blockers, and angiotensin converting enzyme inhibitors have all been tried without success. ${ }^{13}$ The results of studies of the effects of hirudin or self-administered subcutaneous heparin are awaited and a further trial is planned to investigate the therapeutic potential of monoclonal antibodies to the platelet adhesion molecule GIIb/IIIa.

\section{Pathogenesis}

Examination of the nature of the injury produced by the balloon dilatation gives some insight into the pathogenesis of the restenotic lesion. The atheroma is compressed into the wall of the artery but the process, by necessity, also destroys or damages the overlying endothelium and stretches the media and adventitia. Some degree of dissection is probably inevitable. ${ }^{2}$ There is evidence from both experimental models of angioplasty ${ }^{14}$ and from clinical audit ${ }^{15}$ that the development of FCIH is related to the amount of distension of the vessel by the balloon. In the clinical situation this is difficult to control precisely because the relief of the patient's symptoms requires that the lumen size is increased and displacement of the atheroma adds to the direct pressure from the balloon catheter.

Much of the research into the pathogenesis of FCIH after balloon catheter injury has focused on the role of various autocrine and paracrine growth factors and cytokines. As might be expected with an injury that causes stripping of the endothelium and direct physical damage to medial vascular smooth muscle cells and adventitial nerves and vasa vasora, the mediator involvement is complex. Platelet derived growth factor (PDGF), ${ }^{16}$ basic fibroblast growth factor (bFGF), ${ }^{17}$ transforming growth factor beta $(\text { TGF- } \beta)^{18}$ and interleukin-1-alpha ${ }^{19}$ are among the many factors that have been implicated in the 


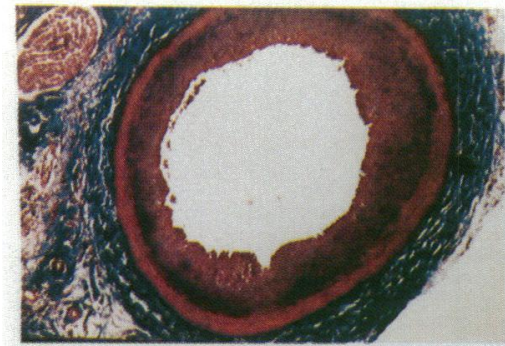

CONTROL

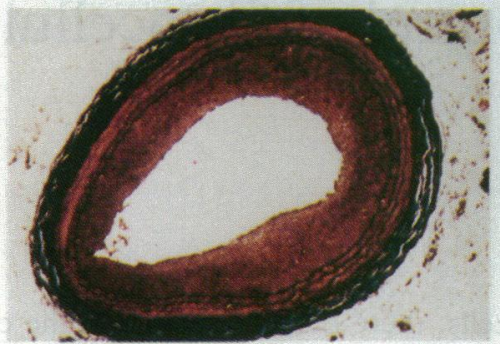

PLURONIC GEL

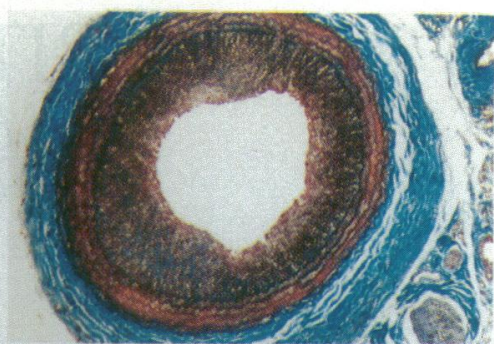

SENSE C-MYB

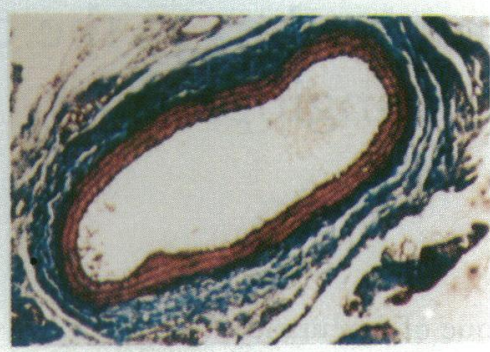

ANTISENSE C-MYB pathogenesis of FCIH. Clearly the response to the balloon catheter injury of the vessel is so fundamental that complex interacting cascades of growth factors ensure the development of FCIH and it is unlikely that a single pivotal factor amenable to pharmacological intervention will be easily identified. In the rat model of FCIH high doses of angiotensin converting enzyme inhibitors substantially inhibit intimal thickening after balloon catheter injury of the rat carotid artery ${ }^{20}$ but clinically relevant doses of ACE inhibitors did not affect the incidence of restenosis after coronary angioplasty. ${ }^{21}$ It may be that the stimulatory cascades of growth factors and cytokines in humans and in the rat have a different balance that influences the response of the lesion to drugs.

\section{New approaches to prevention}

Nevertheless, FCIH develops because of proliferation and migration of vascular smooth muscle cells. However, this response is likely to involve mechanisms fundamental to growth and repair and control of FCIH will probably necessitate the local application of agents that will inhibit either or both proliferation and migration. These may be pharmacological, physical (for example radiation) or genetic. Transfection of cells for subsequent transplantation and direct transfection into the arterial wall of marker genes such as $\beta$-galactosidase, ${ }^{22-24}$ luciferase, ${ }^{25}$ and human adenosine deaminase ${ }^{26}$ and genes of proteins with therapeutic potential such as tissue plasminogen activator $^{27}$ has already been demonstrated. Simons et al successfully inhibited FCIH induced by Fogarty balloon catheter dilatation of the rat carotid by the application of a phosphothiolated antisense $c-m y b$ oligonucleotide to the adventitial surface of the injured vessel (figure).$^{28}$ The proto-oncogenes such as c-fos, c-myc and c-myb are universally expressed during cell division and may be induced by a wide range of stimuli including physical stresses. ${ }^{29}$ 30-32 Antisense oligonucleotides are short lengths of single stranded DNA that are complementary (antisense) to lengths of DNA in part of the target gene or to the RNA transcript from it. The oligonucleotides inhibit the function of the gene by binding to these sequences. ${ }^{33}$ Chemical modification of the oligonucleo- tides confers resistance to degradation by nucleases and improves stability. ${ }^{34}$ Targeting the early cellular responses to injury may minimise any possible inter-species differences in the pathogenesis of the lesion but genes expressed uniquely by proliferating or migrating vascular smooth muscle cells may be more specific targets.

Simons et $a l^{28}$ delivered their synthetic antisense oligonucleotides to the adventitial surface of the injured vessel and clearly this would not be feasible for routine clinical use. However, administration of the therapeutic agents directly to the vessel wall requires only minor modification of catheter hardware already available. Such modifications include double balloons to isolate the segment of artery into which the therapeutic agent is infused via a central pore,,$^{22-24}$ microperforation of the balloon to allow instillation of agents into the wall, and perfusion systems to permit distal blood flow during the procedure $^{25}$ (though instillation of the transfection vector or the oligonucleotide may take only a few minutes). The duration of activity of the modified antisense oligonucleotides or of the duration of expression of transfected genes of proposed therapeutic function, and the longer term effects of retroviral transfection vectors will have to be ascertained before such agents can be applied to humans. Animal models of FCIH will have a pivotal role in these studies and costing, handling, and housing advantages make the rat the natural choice for primary studies though confirmatory studies in pigs or primates may follow. It can be envisaged that in the future percutaneous transluminal coronary angioplasty will be coupled to the local application of a therapeutic agent aimed at inhibiting the development of FCIH and resulting restenosis.

Division of Cardiology,

University College Hospital,

Gower Street, London WC1E 6AU

JEAN MCEWAN

1 Greuntzig AR, King SB, Schlumpf $M$, Seigenthale N. Long term follow up after percutaneous coronary angioplasty. The early Zurich experiup after percutaneous coronary angioplas

2 Waller BF, Orr CM, Pinkerton CA, VanTassel JW, Pinto RP Morphological observations late after balloon angioplasty: mechanisms of acute injury and relationship to restenosis. Radiology 1990;174: 961-7. 
3 Dilley RJ, McGeachie JK, Prendergast FJ. A review of the histological changes in vein to artery grafts, with particular reference to intimal hyperplasia. Arch Surg 1988;123:691-6.

4 Billingham ME. The post-surgical heart - the pathology of cardiac transplantation. Am ₹ Cardiovasc Pathol 1988;1:319-34.

5 Muller DWM, Ellis SG, Topol EJ. Experimental models of coronary artery restenosis. $\mathcal{F} \mathrm{Am}$ Coll Cardiol 1992;19:418-32.

6 Bauriedel G, Windstetter U, DeMaio SJ, Kandolf R, Hofling B. Migratory activity of human smooth muscle cells cultivated from coronary and peripheral primary and restenotic lesions removed by percutaneous atherectomy. Circulation 1992;85:554-64.

7 Kocher O, Gabbiani F, Gabbiani G, et al. Phenotypic features of smooth muscle cells during evolution of experimental carotid artery intimal thickening. Lab Invest 1991;65:459-70.

8 Leclerc G, Isner JM, Kearney M, et al. Evidence implicating non muscle myosin in restenosis. Circulation 1992;85:543-53.

9 Hedin U, Holm J, Hansson GK. Induction of tenascin in rat arterial injury. Am ₹ Pathol 1991;139:649-56.

10 Clowes AW, Clowes MM, Ay YP, Reidy MA, Belin D. Smooth muscle cells express urokinase during mitogenesis and tissue type plasminogen cells express urokinase during mitogenesis and tissue type plasminogen
activator during migration in injured rat carotid artery. Circ Res 1990; activator

11 Lindner V, Reidy MA, Fingerle J. Regrowth of arterial endothelium. Denudation with minimal trauma leads to complete regrowth. Lab Invest 1989;61:556-63.

12 Shimokawa H, Aarhus LL, Vanhoutte PM. Porcine coronary arteries with regenerated endothelium have a reduced endothelium dependent responsiveness to aggregating platelets and serotonin. Circ Res 1987; 61:256-70.

13 Brady A, Warren J. Angioplasty and restenosis. BMF 1991;303:729-30.

14 Capron L, Bruneval P. Influence of applied stress on mitotic response of arteries to injury with a balloon catheter: quantitative study on rat arteries to injury with a balloon catheter:

15 Beatt KJ, Serruys PW, Luijten HE, et al. Restenosis after coronary angioplasty; the paradox of increased lumen diameter and restenosis. $\mathcal{F} \mathrm{Am}$ Coll Cardiol 1992;19:258-66.

16 Jawein A, Bowen-Pope DF, Lindner V, Schwartz SM, Clowes AW. Platelet derived growth factor promotes smooth muscle cell migration and intimal thickening in a rat model of balloon angioplasty. $\mathcal{F}$ Clin Invest 1992;89:507-11.

17 Lindner V, Lappi DA, Baird A, Majack RA, Reidy MA. Role of basic fibroblast growth factor in vascular lesion formation. Circ Res 1991; 68:106-13.

18 Majesky MW, Lindner V, Twardzik DR, Schwartz SM, Reidy MA Production of transforming growth factor $\beta$ during repair of arterial injury. 7 Clin Invest 1991;88:904-10.
19 Brody JI, Pickering NJ, Capuzzi DM, Fink GB, Can CA, Gomez F. Interleukin-1 alpha as a factor in occlusive vascular disease. $\mathrm{Am} \mathrm{f} \mathrm{Clin}$ Pathol 1992;97:8-13.

20 Powell JS, Clozel JP, Muller RK, et al. Inhibitors of angiotensin converting enzyme prevent myointimal proliferation after vascular injury. Science 1989;245:186-8.

21 Mercator study group. Does the new converting enzyme inhibitor cilazipril prevent restenosis after percutaneous transluminal angioplasty. Circulation 1992:86:100-10.

22 Nabel EG, Plautz G, Boyce FM, Stanley JC, Nabel GJ. Recombinant gene expression in vivo within endothelial cells of the arterial wall. Science 1989:244:1342-4.

23 Nabel EG, Plautz G, Nabel GJ. Site specific gene expression in vivo by direct gene transfer into the vessel wall. Science 1990;249:1285-8.

24 Plautz G, Nabel EG, Nabel GJ. Introduction of vascular smooth cells expressing recombinant genes in vivo. Circulation 1991;83:578-83.

25 Chapman GD, Lim CS, Gammon RS, et al. Gene transfer into coronary arteries of intact animals with a percutaneous balloon catheter. Circ Res 1992;71:27-33.

26 Lynch CM, Cloves MM, Osborne WRA, Clowes AW, Miller AD. Long term expression of human adenosine deaminase in vascular smooth muscle cells of rat

27 Dichek DA, Neville RF, Zweibel JA, Freeman SM, Leon MB, Anderson FW. Seeding of intravascular stents with genetically engineered cells. Circulation 1989;80:1347-53.

28 Simons M, Edelman ER, DeKeyser J-L, Langer R, Rosenberg RD. Antisense c-myb oligonucleotides inhibit intimal arterial smooth muscle cell accumulation in vivo. Nature 1992;359:67-70.

29 Evans GI. Introduction: the great nuclear debate. Seminars in Cancer Biology 1990;1:351-8.

30 Izumo S, Nadel-Ginard B, Mahdavi V. Proto-oncogene expression and reprogramming of cardiac gene expression produced by pressure overload. Proc Natl Acad Sci USA 1988;85:339-43.

31 Bennett MR, Evan GI, Newby AC. Central role of the c-myc protooncogene in vascular smooth muscle cell proliferation and cell death [abstract]. Br Heart $\mathcal{F}$ 1993;69(Suppl):P57.

32 Anglin S, Bennett MR, Jagoe R, Evan G, McEwan JR. An antisense oligonucleotide to c-myc inhibits fibrocellular intimal hyperplasia in a rat carotid model of angioplasty [abstract]. Br Heart $\mathcal{f}$ 1993;69(Suppl): P88.

33 Akhtar S, Juliano RL. Antisense DNA oligonucleotides as potential therapeutic agents. Pharm f 1991;247:89-92.

34 Agrawal S, Temsamani J, Tang JY. Pharmacokinetics, biodistribution and stability of oligonucleotide phosphorothiolates in mice. Proc Natl Acad USA 1991;88:7595-9. 